\title{
EXAMINING THE EFFECT OF MOTIVATION ON THE INFLUENCE OF HUMAN RESOURCE PRACTICES AND NORMATIVE COMMITMENT AMONG SMES IN SELANGOR
}

\author{
Elaina Rose Johar ${ }^{1 *}$, Norzanah Mat Nor ${ }^{1}$, Roshidi Hassan ${ }^{1}$ \\ and Rusnifaezah Musa ${ }^{2}$ \\ ${ }^{1}$ Arshad Ayub Graduate Business School, Universiti Teknologi MARA, Malaysia \\ E-mail: ell_r7@yahoo.com.sg,norzanah@salam.uitm.edu.my, \\ roshidih@salam.uitm.edu.my \\ ${ }^{2}$ School of Business Management, College of Business, Universiti Utara Malaysia, \\ E-mail: rusnifaezah@gmail.com
}

\begin{abstract}
Human resources are vital to the success or failure of the organization. However, there exist challenges in maintaining these human resources although human resource practices are deliberated as an important factor to improve employees' commitment to the organization. Hence, this study aimed to investigate the nature of relationship that exists between human resource practices and normative commitment with motivation as the mediator. Employed a quantitative research approach, 64 SME employees in Selangor were surveyed. It was found that all human resource practices have positive effect on normative commitment with compensation, training and employee involvement-decision being significant. This study also revealed that motivation has a mediating effect for the relationship of training and both employee involvement with normative commitment. Thus, it can be concluded that both training and employee involvement create sense of loyalty and obligation to stay when employees are motivated.
\end{abstract}

Keywords: human resource practices, motivation and normative commitment

\section{ARTICLE INFO}

Article History:

Received: 23 December 2018

Accepted: 25 March 2019

Published: 30 April 2019 


\section{INTRODUCTION}

Having new generations coming into the labor market, most organizations are currently fighting in a war of talent. Undoubtedly, human resources in the organization indispensably lead to the success or failure of the organization and what each employee brings to the organization is unique and not easily imitated (Subramaniam, Faridahwati Mohd Shamsudin \& Hadziroh Ibrahim, 2011). Consequently, human resource practices are deliberated as an important factor to improve employees' commitment to the organization and that organizational commitment is the pillar of the modern HRM philosophy as well as the strength that binds HRM practices (Mahal, 2012; Mulolli, Islami \& Skenderi, 2015; Osa \& Amos, 2014). When employees are more committed to the organization, the more motivated they would be and more willing to work 'above and beyond contract'; committed employees feel a greater responsibility, thus reducing the manager's need to monitor and supervise; and committed employees are expected less likely to leave the organization, resulting in the reduction of recruitment and selection expenditures (Mahal, 2012).

Notably, with reference to Table 1, small and medium sized enterprises (SMEs) in Malaysia play an important role in ensuring the growth of the Malaysian economy with its contribution to the overall GDP of $36.6 \%$ in 2016 (SME, 2017). Furthermore, lack of job readiness, low utilization of existing training programs and non-competitive rewards and benefits among SMEs workforce are among the key challenges of human capital development identified in the SME Master Plan 2012-2020. Thus, these identified challenges make it critical for SMEs to properly manage their human resources, as it is important to note that previous studies have yet to tackle issues pertaining to HRM in SMEs as compared to larger firms such as low employee commitment and switching job frequently (Cardon \& Stevens, 2004; Fazzari \& Mosca, 2009; Grigore, 2013; National SME Development Council, 2012; Szamosi, 2006). Hence, this study focused on the employees' commitment resulting from the implementation of human resources practices among service organizations in Malaysian SME as research on service sector firms is scarce. Also, this study aimed to examine the mediating role of motivation in the relationship between human resource practices and employee commitment in SMEs in Selangor (Hooi \& Ngui, 2014; Jones, Kalmi \& Kauhanen, 2010; Shin \& Konrad, 2014). 
Table 1: SME GDP by Key Economic Activity (constant 2010 prices)

\begin{tabular}{lcccc}
\hline & \multicolumn{3}{c}{ SME Contribution to GDP } & $\begin{array}{c}\text { SME GDP } \\
\text { Growth }\end{array}$ \\
\cline { 2 - 5 } & $\begin{array}{c}\mathbf{2 0 1 0} \\
\text { (\% share) }\end{array}$ & $\begin{array}{c}\text { 2016 } \\
\text { (\% share) }\end{array}$ & $\begin{array}{c}\text { Increase/ } \\
\text { decrease in share }\end{array}$ & $\begin{array}{c}\text { 2011-2016 } \\
\text { CAGR }\end{array}$ \\
\hline Overall ${ }^{2}$ & 32.2 & 36.6 & +4.4 & 6.5 \\
Agriculture & 4.3 & 4.1 & -0.2 & 2.2 \\
Mining \& Quarrying & 0.05 & 0.2 & +0.15 & 9.1 \\
Manufacturing & 7.2 & 7.9 & +0.7 & 6.4 \\
Construction & 0.9 & 2.1 & +1.2 & 10.2 \\
Services & 19.6 & 21.8 & +2.2 & 7.0 \\
\hline
\end{tabular}

${ }^{1}$ CAGR refers to compounded annual growth rate (underlying growth of $7.9 \%$ for 2014)

${ }^{2}$ Total value-added after taking into account import duties

Source: Department of Statistics, Malaysia

\section{LITERATURE REVIEW}

\section{Employee Commitment}

Organizational commitment is a belief, significantly related to employees' perceptions of the employer's commitment to them as they reciprocate their perceptions of the organization's actions in their own attitudes and behavior (Osa \& Amos, 2014; Shore \& Tetrick, 1991). Commitment as conceptualized is referred to as affective, continuance, and normative commitment (Meyer \& Allen, 1991). It views commitment as a psychological state that (a) characterizes the employee's relationship with the organization, and (b) has implications for the decision to continue or discontinue membership in the organization. In this context, normative commitment reflects a feeling of obligation to continue employment. Employees with a high level of normative commitment feel that they ought to remain with the organization.

\section{Human Resource Practices and Employee Commitment}

Practices has always been defined upon HRM as a set of practices rather than a more general process of incorporating human resource decisions at a strategic level (Duberley \& Walley, 1995). Only recently, organizations have realized the potential role of HRM in augmenting the 
organization's performance. Previously organizations have s overlooked the purpose of HRM in contributing to organizational success (Zakaria, Mohamed Zainal \& Mohd Nasurdin, 2011). Additionally, SMEs might use HRM in different ways and are less likely to formalize as compared to larger organizations. Thus it is a valuable starting point to initiate an investigation as SMEs generally emphasize on specific practices (Abdul Hamid, Baharun \& Hashim, 2006; Cassell, Nadin, Gray \& Clegg, 2002). As suggested by (Guest, 1997), this study has conceptualized human resource practices as consisting of compensation, training, recruitment and employee involvement, the dominant dimensions that are being focused by most human resource studies to explain variance in the construct. Additionally, Cardon and Stevens (2004) have reviewed the literature that summarized compensation as the second most focused topic in the relationship of HRM and entrepreneurship because compensation notably affects recruiting and retention efforts of small firms as critical skills or knowledge cannot be recruited, retained or operated effectively if they cannot pay the candidates enough. Ultimately, salary, bonus and compensation have a significant positive efect on employee commitment (Coetzee, Mitonga-Monga \& Swart, 2014; Hassan \& Mahmood, 2016; Hashim, Ismail \& Hassan, 2016; Lin, Lin \& Lin, 2012). Correspondingly, employees are more willing to stay in the organization, which provide better economic rewards, salary and bonus.

On the same note, training denotes the methods used to give new or present employees the skills, knowledge behaviors and other abilities they need to perform their jobs, modify individuals' skills or attitudes as well as help in the development of positive dispositions towards growth and change as ratified by individuals, groups and teams (DeNisi \& Griffin, 2001; Herold \& Fedor, 2003; Lyons, 2009). Accordingly, training and development remain as among the important practices for augmenting both the affective and normative commitment of professional qualified engineers in South Africa as they were fortified with skills and knowledge through formal and informal training opportunities (Coetzee et al., 2014). Additionally, appropriate training and development given by the organizations would lead to greater efficiency and effectiveness and productivity as a whole (Ihionkhan \& Aigbomian, 2014). Separately, training on job skills contributed to weak and positive relation with organizational commitment (Sendogdu, Kocabacak \& Guven, 2013). 
Besides that, staffing was found to be important to both employees' commitment and satisfaction particularly in the micro enterprise firms in Malaysia (Hashim et al., 2016). Moreover, empirical evidence indicate that outsourcing recruitment process has no impact on both employee commitment and loyalty (Jamil \& Naeem, 2013). Finally, Adham (2011) suggested two types of direct employee involvement (EI) that is (EIautonomy and EI-decision). EI-autonomy was found to have a positive impact on satisfaction and commitment when authority is given to employees in terms of their daily work and EI-decision was found to have more influence on both satisfaction and commitment when employees are kept in the loop and permitted to influence final decisions. Additionally, employee involvement was found to have a positive relation with affective and normative commitment (Chelliah, Sundarapandiyan \& Vinoth., 2015). Hence, based on the previously stated studies, the current study hypothesized that:

$\mathbf{H}_{1 \mathbf{a}}$ : There is a significant relationship between compensation and employee commitment

$\mathbf{H}_{\mathbf{1 b}}$ : There is a significant relationship between training and employee commitment

$\mathbf{H}_{1 \mathbf{c}}$ : There is a significant relationship between recruitment and employee commitment

$\mathbf{H}_{\mathbf{1 d}}$ : There is a significant relationship between employee involvementautonomy and employee commitment

$\mathbf{H}_{1 \mathrm{e}}$ : There is a significant relationship between employee involvementdecision and employee commitment

\section{Motivation and its Role as Mediator}

In describing the relationship between HRM and commitment, previous studies have looked into the "black box" of the linkage and the AMO (ability, motivation and opportunity) framework is one of the popular variables used (Appelbaum et al., 2000). Furthermore, Obeidat, Mitchell and Bray (2016) proposed for further future research should investigate the interaction between each of the AMO dimensions to enable a clearer specification of the possible moderator and mediator effects in the study model. Hence, motivation is the employee's desire to perform, which can be improved by extrinsic or intrinsic motivation (Kim, Pathak \& Werner, 2015; Marin-garcia \& Tomas, 2016). Extrinsic factors are related 
to incentives whereas intrinsic factors come from individual's interests and values (Minbaeva, 2012; Schimansky, 2014). Moreover, in the HRM setting, motivation-enhancing practices can ensure employees give their best in completing organizational objectives and produce a high level of performance (Marin-garcia \& Tomas, 2016). Based on discussions above, the following hypotheses are proposed:

$\mathbf{H}_{2 \mathbf{a}}$ : Motivation mediates the relationship between compensation and employee commitment

$\mathbf{H}_{2 \mathbf{b}}$ : Motivation mediates the relationship between training and employee commitment

$\mathbf{H}_{2 \mathbf{c}}$ : Motivation mediated the relationship between recruitment and employee commitment

$\mathbf{H}_{2 \mathrm{~d}}$ : Motivation mediates the relationship between employee involvementautonomy and employee commitment

$\mathbf{H}_{2 \mathrm{e}}$ : Motivation mediates the relationship between employee involvementdecision and employee commitment

\section{METHODOLOGY}

This pilot study utilized the primary data collection method and a quantitative approach to data analysis. A questionnaire survey was used to collect a cross sectional data. The measurement of normative commitment (6 items) was adapted from Meyer and Allen (1991), motivation (7 items) from Guay, Vallerand and Blanchard (2000), human resource practices which comprised of recruitment ( 7 items) adapted from (Geringer, Frayne \& Milliman, 2002), training (7 items) adopted from (Delery \& Doty, 1996; Geringer et al., 2002; Vandenberg, Richardson \& Eastman, 1999; Wayne, Shore \& Liden, 1997), compesation (7 items) adapted from (Geringer et al., 2002; Moynihan, Gardner \& Wright, 2002; Snell \& Dean, 1992; Vandenberg et al., 1999), employee involvement of autonomy (5 items) and employee involvement of decision (8 items) adapted from (Adham, 2011). According to Rowley (2014), many studies depend on non-probability samples, often purposive, convenience or snowball samples, as a result of the difficulties associated with creating sufficiently comprehensive sampling frames. Most researchers agree that some data is better than no data. However, it is still crucial to know the extent to which the sample is aligned with its population and post-hoc checks on representativeness can be conducted by comparing 
the study sample with some key external statistics relevant to the study. Correspondingly, Table 2 shows that there are 179,271 SMEs in Selangor. The purposive sampling technique was used for the respondent pool. Again, Rowley (2014) suggested that the sample for purposive sampling is "handpicked" for the research when the researcher already knows something about the specific cases and deliberately selects specific ones because they are likely to produce the most valuable data. A total of 100 questionnaires were distributed to SMEs employees based on the list of SMEs organization in service sector provided in the SME Corp Malaysia website. This study managed to obtain a response rate of $64 \%$. The data collected were analyzed using multiple and hierarchical regression through the SPSS version 23. The data were cleaned from any missing data and outliers.

Table 2: Number of Establishment by State

\begin{tabular}{lcc}
\hline & Total SMEs & $\%$ \\
\hline Selangor & 179,271 & 19.8 \\
WP Kuala Lumpur & 133,703 & 14.7 \\
Johor & 98,190 & 10.8 \\
Perak & 75,140 & 8.3 \\
Pulau Pinang & 66,921 & 7.4 \\
Sarawak & 61,036 & 6.7 \\
Sabah & 55,702 & 6.2 \\
Kedah & 48,894 & 5.4 \\
Kelantan & 46,618 & 5.1 \\
Pahang & 37,573 & 4.1 \\
Negeri Sembilan & 32,721 & 3.6 \\
Melaka & 31,361 & 3.5 \\
Terengganu & 29,324 & 3.2 \\
Perlis & 6,808 & 0.8 \\
WP Labuan & 2,567 & 0.3 \\
WP Putrajaya & 1,236 & 0.1 \\
Total SMEs & 907,065 & 100.0 \\
\hline
\end{tabular}

Source: Economic Census 2016, Profile of Small and Medium Enterprises (reference year 2015), Department of Statistics, Malaysia 
Additionally, factor analysis was conducted to determine if the measures or items are loaded on the appropriate factors as identified by previous researchers (Venkatraman, 1989). Meanwhile the reliability test was conducted to examine the internal inconsistency of the constructs employed in this study; employee commitment, human resource practices and motivation. Factor analysis was conducted for the human resource practices construct only to validate the dimensions of the human resource practices (Table 3 ). The measurement scales for human resource practices consisted of 25 items and varimax rotated principal components factor analysis was then conducted. Prior to this, the suitability of the data for factor analysis was assessed. Only loadings of at least 0.30 were included in the factor (Hair et al., 2006).

Table 3: Factor Analysis on Human Resource Practices

\begin{tabular}{|c|c|c|}
\hline Factor 1 & Description of Items & Loadings \\
\hline R3 & $\begin{array}{l}\text { Hiring decisions here are based on proven work } \\
\text { experience in a similar job. }\end{array}$ & 0.806 \\
\hline $\mathrm{R} 4$ & $\begin{array}{l}\text { Hiring decisions here are influenced by how well the } \\
\text { person will fit the company's values and ways of doing } \\
\text { things. }\end{array}$ & 0.693 \\
\hline R6 & $\begin{array}{l}\text { Hiring decisions here are influenced by future co- } \\
\text { worker's opinions about whether the person should be } \\
\text { hired. }\end{array}$ & 0.648 \\
\hline \multicolumn{2}{|c|}{ Percentage variance } & 7.204 \\
\hline Factor 2 & Description of Items & Loadings \\
\hline $\mathrm{C} 4$ & Raises and promotions are tied to performance & 0.864 \\
\hline C3 & Pay is tied to performance & 0.854 \\
\hline C1 & $\begin{array}{l}\text { Pay raises for employees in this job are based on job } \\
\text { performance. }\end{array}$ & 0.796 \\
\hline \multicolumn{2}{|c|}{ Percentage variance } & 10.891 \\
\hline Factor 3 & Description of Items & Loadings \\
\hline $\mathrm{T} 1$ & $\begin{array}{l}\text { I am given a real opportunity to improve my skills at this } \\
\text { company through education and training programs. }\end{array}$ & 0.838 \\
\hline T4 & $\begin{array}{l}\text { I receive on-going training, which enables me to do my } \\
\text { job better. }\end{array}$ & 0.837 \\
\hline T5 & $\begin{array}{l}\text { I am satisfied with the quality of training and development } \\
\text { programs available to me. }\end{array}$ & 0.833 \\
\hline T6 & $\begin{array}{l}\text { Training helps me to improve my interpersonal abilities, } \\
\text { i.e. how well I relate to others. }\end{array}$ & 0.793 \\
\hline
\end{tabular}


T3 My supervisor helped me acquire some additional job training when I needed.

T2 I have had sufficient job-related training. ways of doing things.

\begin{tabular}{|c|c|c|}
\hline \multicolumn{2}{|c|}{ Percentage variance } & \multirow{2}{*}{$\begin{array}{l}22.888 \\
\text { Loadings }\end{array}$} \\
\hline Factor 4 & Description of Items & \\
\hline $\mathrm{E} 17$ & $\begin{array}{l}\text { How good are managers at informing employees about } \\
\text { changes in staffing? }\end{array}$ & 0.872 \\
\hline El8 & $\begin{array}{l}\text { How good are managers at informing staff about } \\
\text { changes in the way you do your job? }\end{array}$ & 0.850 \\
\hline El9 & $\begin{array}{l}\text { How good are managers at informing staff about financial } \\
\text { matters? }\end{array}$ & 0.808 \\
\hline El10 & $\begin{array}{l}\text { How good are managers at seeking views of employees/ } \\
\text { workers representatives? }\end{array}$ & 0.799 \\
\hline El6 & $\begin{array}{l}\text { How good are managers at telling staff about changes } \\
\text { in how the organization is run? }\end{array}$ & 0.789 \\
\hline El11 & $\begin{array}{l}\text { How good are managers at responding to suggestions } \\
\text { from employees/workers representatives? }\end{array}$ & 0.750 \\
\hline El12 & $\begin{array}{l}\text { How good are managers at allowing employees/workers } \\
\text { representatives influence final decisions? }\end{array}$ & 0.642 \\
\hline \multicolumn{2}{|c|}{ Percentage variance } & 22.041 \\
\hline Factor 5 & Description of Items & Loadings \\
\hline $\mathrm{El} 2$ & $\begin{array}{l}\text { In general how much influence do you have over the } \\
\text { pace at which you work? }\end{array}$ & 0.884 \\
\hline El5 & $\begin{array}{l}\text { In general how much influence do you have on time start/ } \\
\text { finish working day? }\end{array}$ & 0.864 \\
\hline $\mathrm{El} 3$ & $\begin{array}{l}\text { In general how much influence on order for you to carry } \\
\text { out tasks? }\end{array}$ & 0.853 \\
\hline El1 & $\begin{array}{l}\text { In general how much influence do you have over the } \\
\text { tasks you do? }\end{array}$ & 0.838 \\
\hline El4 & $\begin{array}{l}\text { In general how much influence do you have in how you } \\
\text { do your work? }\end{array}$ & 0.820 \\
\hline \multicolumn{2}{|c|}{ Percentage variance } & 16.544 \\
\hline \multicolumn{2}{|c|}{ Total percentage variance } & 79.569 \\
\hline \multicolumn{2}{|c|}{ Kaiser Meyer Olkin Measure of Sampling Adequacy } & 0.854 \\
\hline \multicolumn{3}{|c|}{ Bartlett's Test of Sphericity: } \\
\hline \multicolumn{2}{|c|}{ Approx. Chi-Square } & 1587.285 \\
\hline \multicolumn{2}{|l|}{ DF } & 300 \\
\hline \multicolumn{2}{|l|}{ Sig. } & 0.000 \\
\hline
\end{tabular}


The Kaiser-Meyer-Olkin (KMO) measure of sampling adequacy for the items were 0.854 , exceeding the recommended value of 0.6 Kaiser (1974), and thus interpreted as in the range of "fair" (Hutcheson, Graeme \& Sofroniou, 1999). Barlett's Test of Sphericity was also found to be significant at $p<0.001$, with the approximate Chi-Square value of 1587.285, indicating the appropriateness of the correlations among the variables and thus provide a sufficient basis for factor analysis (Durbin, James \& Geoffrey, 1951). Consequently, the factor analysis resulted in five factors with an eigenvalue greater than 1 that explained 79.56 percent of variance in the data. The first factor reflected the recruitment dimension accounted for 7.20 percent of the total variance with an eigenvalue of 1.801 . The second factor consisted of three items of compensation, which accounted for 10.89 percent of the total variance in the data. The eigenvalue was 2.723. Besides that, the third factor represented by seven factors classified as training and accounted for 22.89 percent of the total variance with an eigenvalue of 5.722. Additionally, the forth factor consisted of seven items of employee involvement-decision, which comprised of 22.04 percent of the total variance in the data with eigenvalue of 5.510. Finally, the fifth factor of employee involvement-autonomy accounted for 16.54 percent of the total variance with an eigenvalue of 4.136 .

Table 4 indicates the results of internal consistency of the variables. The scores of reliability coefficient after factor analysis showed most of the variables achieved strong scores for reliability. Only recruitment variables achieved moderate scores at 0.583 . This score indicates that the strength of association between items is excellent as it achieved more than 0.9 scores but not more than 0.95 as highlighted by Hair et al. (2006) that scores above 0.95 will lead to a multicollinearity problem. 
Table 4: Reliability Coefficient After Factor Analysis

\begin{tabular}{lcc}
\hline Variable & $\begin{array}{c}\text { Number of } \\
\text { Items }\end{array}$ & $\begin{array}{c}\text { Cronbach's } \\
\text { Alpha }\end{array}$ \\
\hline Normative commitment & 4 & 0.905 \\
Motivation & 5 & 0.880 \\
Recruitment & 3 & 0.583 \\
Compensation & 3 & 0.925 \\
Training & 7 & 0.953 \\
Employee involvement (autonomy) & 5 & 0.927 \\
Employee involvement (decision) & 7 & 0.953 \\
\hline
\end{tabular}

\section{RESULT AND ANALYSIS}

\section{Descriptive Analysis}

Table 5 shows the respondent's demographic profile that described the background of SMEs employees. Both genders were well represented with female respondents at 67.2 percent and male respondents at 32.8 percent. In addition, the findings of the SME employees' age was dominated by the respondents aged $26-35$ years old (75.0 percent), followed by respondents who are at $36-45$ years old (18.8 percent). The academic qualifications of respondents showed most of the employees are bachelor degree holders at 71.9 percent. About 95.3 percent of respondents have work experiences of more than one year whereby 50.0 percent of the respondents have 2 to 5 years' work experience, 28.1 percent have 6 to 10 years work experience, 14.1 percent have 11- 15 years of work experience and 3.1 percent of the respondents have more than 16 years of work experience. Meanwhile, the employees demographic profile shows that a majority of the employees are in the executive position (45.3 percent), followed by non-executive position (25.0 percent) and managerial position (29.7 percent). Majority of the respondents (78.1 percent) have income above RM 3000. 
Table 5: Profile of Respondents

\begin{tabular}{|c|c|c|}
\hline & Frequency & Percent \\
\hline \multicolumn{3}{|l|}{ Gender } \\
\hline Male & 21 & 32.8 \\
\hline Female & 43 & 67.2 \\
\hline Total & 64 & 100.0 \\
\hline \multicolumn{3}{|l|}{ Age Group } \\
\hline$<25$ years old & 4 & 6.3 \\
\hline $26-35$ years old & 48 & 75.0 \\
\hline $36-45$ years old & 12 & 18.8 \\
\hline Total & 64 & 100.0 \\
\hline \multicolumn{3}{|l|}{ Academic qualification } \\
\hline Diploma & 2 & 3.1 \\
\hline Bachelor Degree & 46 & 71.9 \\
\hline Master Degree & 13 & 20.3 \\
\hline Phd & 2 & 3.1 \\
\hline Others & 1 & 1.6 \\
\hline Total & 64 & 100.0 \\
\hline \multicolumn{3}{|l|}{ Years of service } \\
\hline 1 year or less & 3 & 4.7 \\
\hline $2-5$ years & 32 & 50.0 \\
\hline $6-10$ yeras & 18 & 28.1 \\
\hline $11-15$ years & 9 & 14.1 \\
\hline More than 15 years & 2 & 3.1 \\
\hline Total & 64 & 100.0 \\
\hline \multicolumn{3}{|l|}{ Level of position } \\
\hline General Manager & 2 & 3.1 \\
\hline Manager & 12 & 18.8 \\
\hline Assistant Manager & 5 & 7.8 \\
\hline Executive & 29 & 45.3 \\
\hline Others & 16 & 25.0 \\
\hline Total & 64 & 100.0 \\
\hline \multicolumn{3}{|l|}{ Monthly income (RM) } \\
\hline Less than 1000 & 1 & 1.6 \\
\hline $1000-3000$ & 13 & 20.3 \\
\hline $3001-5000$ & 31 & 48.4 \\
\hline $5001-7000$ & 14 & 21.9 \\
\hline 7001 and greater & 5 & 7.8 \\
\hline Total & 64 & 100.0 \\
\hline
\end{tabular}




\section{Correlation Analysis}

The independent variables (compensation, training and employee involvement-decision) as well as the mediator (motivation) had a significant relationship with the dependent variable, normative commitment (NC). Training (HR_T), employee involvement-decision (HR_EI(D)) and motivation (M) were correlated with normative commitment (NC) at the significance level $\mathrm{p}<0.01$. Meanwhile, the variable compensation (HR_C) correlated with $\mathrm{NC}$ at the significance level $\mathrm{p}<0.05$ In addition, recruitment (HR_R) and employee involvement-autonomy (HR_EI(A)) had an insignificant relationship with NC (Table 6).

Table 6: Pearson Correlation Result

\begin{tabular}{lccccccc}
\hline Variable & NC & $M$ & HR_R & HR_C & HR_T & $\begin{array}{c}\text { HR_El } \\
(\mathbf{A})\end{array}$ & $\begin{array}{c}\text { HR } \\
\text { EI(D) }\end{array}$ \\
\hline NC & 1 & & & & & & \\
$M$ & $0.427^{* * *}$ & 1 & & & & & \\
HR_R & 0.107 & $0.258^{* *}$ & 1 & & & & \\
HR_C & $0.288^{* *}$ & $0.330^{* * *}$ & $0.225^{*}$ & 1 & & & \\
HR_T & $0.606^{* * *}$ & $0.369^{* * *}$ & $0.283^{* *}$ & $0.516^{* * *}$ & 1 & & \\
HR_EI(A) & 0.016 & $0.512^{* * *}$ & $0.383^{* * *}$ & $0.370^{* * *}$ & $0.317^{* *}$ & 1 & \\
HR_EI(D) & $0.517^{* * *}$ & 0.198 & 0.190 & $0.419^{* * *}$ & $0.743^{* * *}$ & $0.305^{* *}$ & 1 \\
\hline
\end{tabular}

Note: Normative Commitment (NC), Motivation (M), Recruitment (HR_R), Compensation (HR_C), Training (HR_T), Employee Involvement-Decision (HR_El(D)), Employee Involvement-Autonomy (HR_El(A)). Correlation significance *: $p<0.1,{ }^{* *}: \mathrm{p}$ $<0.05,{ }^{* \star *}: \mathrm{p}<0.01,2$-tailed.

\section{Hierarchical Regression Analysis}

Table 7 reports the findings of motivation as a mediator through hierarchical analysis. Model 1 indicates a good fit of the model where 64.6 percent explains all the variability of the response data around its mean. Training has a significant effect on normative commitment at $(\mathrm{p}<0.01)$ and employee involvement-autonomy had a negative significant effect on normative commitment at $(p<0.1)$. Significance of $F$ change also indicates a significance value for the model. Therefore, H1b and H1d are accepted.

In Model 2, the variable, motivation (M) was included and resulted in an increment in $\mathrm{R}$ squared at 0.553 . In this model also, $\mathrm{M}$ was found to have a significant effect on normative commitment at $(b=0.452, p<0.01)$. Meanwhile, employee involvement-autonomy (HR_EI(A)) was found to 
have a negative significant effect at $(b=-0.411, p<0.01)$ and a positive significant effect on employee involvement-decision (HR_EI(D)) at (b $=0.290, \mathrm{p}<0.05)$ and training $\left(\mathrm{HR} \_\right.$Training $)$at $(\mathrm{b}=0.366, \mathrm{p}<0.01)$. Results in model 2 yielded a better increment in the value of $\mathrm{R}$ with the model where $\left(\mathrm{R}=0.743, \mathrm{R}^{2}=0.553, \mathrm{Adj} . \mathrm{R}^{2}=0.506\right)$. This finding proved that the mediator variable; motivation enhanced the model, where the significance of $\mathrm{F}$ change was found to have a significant effect at $\mathrm{p}<0.01$. Furthermore, this finding indicated that motivation mediated the relationship between human resource practices (training and employee involvement) and normative commitment among SMEs employees in Selangor. Thus, we accept $\mathrm{H} 2 \mathrm{~b}, \mathrm{H} 2 \mathrm{~d}$ and $\mathrm{H} 2 \mathrm{e}$.

Table 7: Hierarchical Regression Result

\begin{tabular}{lcc}
\hline \multicolumn{1}{c}{ Independent Variable } & Model 1 & Model 2 \\
\hline Model variable & & \\
HR_Recruitment & 0.000 & -0.007 \\
HR_Compensation & 0.017 & -0.018 \\
HR_Training & $0.531^{* * *}$ & $0.366^{* *}$ \\
HR_Employee Involvement (Autonomy) & $-0.215^{*}$ & $-0.411^{* * *}$ \\
HR_Employee Involvement (Decision) & 0.182 & $0.290^{* *}$ \\
\hline Mediating variable & & \\
Motivation (M) & & $0.452^{* * *}$ \\
\hline$R$ & $0.646^{a}$ & $0.743^{b}$ \\
\hline$R^{2}$ & 0.417 & 0.553 \\
\hline Adj. $R^{2}$ & 0.367 & 0.506 \\
\hline Sig. F Change & 0.000 & 0.000 \\
\hline
\end{tabular}

\section{FINDINGS AND DISCUSSION}

The purpose of this study was to investigate the relationship between HR practices (compensation, recruitment, training and employee involvement) towards normative commitment of SMEs employees in Selangor and to determine the role of motivation as the mediating variable. The previous findings of correlation analysis portrayed that the human resource practices of recruitment, training, compensation and both employee involvement were positively related with normative commitment. Training was found to have a positive significant effect in this model. This findings aligned with previous work (Bashir \& Long, 2015; Coetzee et al., 2014; Yang, 
Sanders \& Bumatay, 2012). However, an opposite result exists whereby training on job skills contributed to a weak relation with organizational commitment (Sendogdu et al., 2013). It can be postulated that the more training opportunities given to employees, the more motivated they will become and more committed to the organization. Also, appropriate training given to employees, will increase their level of confidence and the ability to complete the tasks given. Moreover, employees will have motivation to go to work everyday and lead to a feeling of obligation to stay in the organization as a result of reciprocation for the additional skills obtained from the training provided to them. On top of that, the significant findings on both employee involvement are consistent with previous research (Adham, 2011; Chelliah et al., 2015; Zopiatis, Constanti \& Theocharous, 2014). Surprisingly, before motivation was put in the model as a mediator, the result for employee involvement-decision was insignificant but after it was added, the result became significant. This proves that, when employees are empowered to make decisions and always kept in the loop of what is happening in the work setting, they will become more motivated as they feel that their voices are heard and consequently increase their sense of responsibility for the job.

The findings showed that compensation and recruitment had insignificant results. Conversely, previous work have found significant effects of compensation with employee commitment (Coetzee et al., 2014; Hassan \& Mahmood, 2016; Hashim et al., 2016; Lin et al., 2012). Consequently, it shows that money or remuneration is no longer a motivational urge for employees to become committed and obliged in an organization. Rather, there exists other ways to earn an extra income instead of depending on the fixed salary. In today's digital era, it is possible for employees to find alternatives to earn passive income without neglecting their daily work routines such as online businesses. Likewise, recruitment showed an insignificant result. Nonetheless, previous findings confirmed that recruitment or staffing to be important to both employees' commitment and satisfaction (Hashim et al., 2016). As a matter of fact, the lack of ability of SMEs to find the right candidates that fulfill the criteria in the process of hiring potential employees leads to this problem. Most employers feel that hiring is just a matter of filling a vacant position and perceives that fresh graduates need to secure a job rather than really looking for a job that matches their academic qualification or experiences. Thus, it contributes to 
the lack of motivation and passion to the job. Eventually, employees will become demotivated and couldn't care less about being obligated.

\section{CONCLUSION}

This pilot study provided timely and much needed insights into what drives employees to commit and remain at a particular organization. The findings may aid in understanding what drives the employees on a day-to-day level in the workplace and what drives their career in terms of overarching goals. In this context, in order for SMEs to grasp a greater impact on employee commitment specifically normative commitment, it is important for them to take note of the mediating effects of motivation. Motivation can be the compelling key metrics for organizations especially for owners, managers and HR practitioners to create a positive impact towards employee commitment. These findings can help organizations to realign their approach towards employees and deliver more effective methods in recognizing and valuing them. Finally, this study highlights the findings that are related to the identified objectives, as well as research contribution to different parties. This study results represent a small fraction in understanding the complexity of employee commitment as well motivation and thus cannot be generalized. Future studies should adopt the proposed research model among different types of SMEs to generalize the findings and explore other relevant mediators or perhaps moderators by duplicating the method used in this present study. It is believed that such a research would provide new, meaningful perspectives to the body of knowledge and offer greater insights for the management as well as practitioners in managing the smooth and sophisticated characteristics of employees particularly in SMEs.

\section{REFERENCES}

Abdul Hamid, A. B., Baharun, R., \& Hashim, N. H. (2006). Comparative analysis of managerial practices in small medium enterprises in Malaysia. Jurnal Kemanusiaan, 8, 34-45.

Adham, A. (2011). Employee involvement and its impact on job satisfaction and organisational commitment. International Journal of Sciences: Basic and Applied Research, 18(2), 368-400. 
Appelbaum, E., Bailey, T., Berg, P., \& Kalleberg, A. L. (2000). Manufacturing advantage: Why high-performance work systems pay off. London: ILR Press.

Bashir, N., \& Long, C. S. (2015). The relationship between training and organizational commitment among academicians in Malaysia. Journal of Management Development, 34(10), 1227-1245.

Cardon, M. S., \& Stevens, C. E. (2004). Managing human resources in small organizations: What do we know? Human Resource Management Review, 14, 295-323.

Cassell, C., Nadin, S., Gray, M., \& Clegg, C. (2002). Exploring human resource management practices in small and medium sized enterprises. Personnel Review, 31(6), 671-692.

Chelliah, S., Sundarapandiyan, N., \& Vinoth, B. (2015). A research on employees' organisational commitment in organisations: A case of SMEs in Malaysia. International Journal of Managerial Studies and Research, 3(7), 10-18.

Coetzee, M., Mitonga-Monga, J., \& Swart, B. (2014). Human resource practices as predictors of engineering staff's organisational commitment. SA Journal of Human Resource Management, 12(1), 1-9.

Delery, J. E., \& Doty, D. H. (1996). Modes of theorizing in strategic human resource management : Tests of universalistic, cotigency and configurational performance predictions. Academy of Management Journal, 39(4), 802-835.

DeNisi, A. S., \& Griffin, R. W. (2001). Human resources management. New York, NY: Houghton Mifflin Company.

Duberley, J. P., \& Walley, P. (1995). Assessing the adoption of HRM by small and medium-sized manufacturing organizations. The International Journal of Human Resource Management, 6(4), 891-909. 
Fazzari, A. J., \& Mosca, J. B. (2009). Partners in perfection: Human resources facilitating creation and ongoing implementation of selfmanaged manufacturing teams in a small medium enterprise. Human Resource Development Quarterly, 20(3), 353-376.

Geringer, J. M., Frayne, C. A., \& Milliman, J. F. (2002). In search of "best practices" in international human resource management: Research design and methodology. Human Resource Management, 41(1), 5-30.

Grigore, A. M. (2013). Highlights on the HRM in SME's-A Romanian study case. International Journal of Business and Social Science, 4(3), 73-78.

Guay, F., Vallerand, R. J., \& Blanchard, C. (2000). On the assessment of situational intrinsic and extrinsic motivation: The Situational Motivation Scale (SIMS). Motivation and Emotion, 24(3), 175-213.

Guest, D. E. (1997). Human resource management and performance: A review and research agenda. The International Journal of Human Resource Management, 8(3), 263-376.

Hashim, J. Ismail, Y. \& Hassan, A. (2016). Formality of HRM Practices Matters to Employees Satisfaction and Commitment. Journal of Human Resources Management and Labor Studies, 4(1), 47-64.

Hassan, S., \& Mahmood, B. (2016). Relationship between HRM practices and organizational commitment of employees: An empirical study of textile sector in Pakistan. International Journal of Academic Research in Accounting, Finance and Management Sciences, 6(1), 23-28.

Herold, D. M., \& Fedor, D. B. (2003). Individual differences in feedback propensities and training performance. Human Resource Management Review, 13, 675-689.

Hooi, L. W., \& Ngui, K. S. (2014). Enhancing organizational performance of Malaysian SMEs The role of HRM and organizational learning capability. International Journal of Manpower, 35(7), 973-995. 
Ihionkhan, P. A., \& Aigbomian, E. E. (2014). The influence of human resource management practices on organisational commitment: A study of manufacturing organisations in Nigeria. Indian Journal of Commerce \& Management Studies, 5(1), 18-28.

Jamil, R., \& Naeem, H. (2013). The impact of outsourcing external recruitment process on the employee commitment and loyalty: Empirical evidence from the telecommunication sector of Pakistan. IOSR Journal of Business and Management, 8(2), 69-75.

Jones, D. C., Kalmi, P., \& Kauhanen, A. (2010). How does employee involvement stack up ? The effects of human resource management policies on performance in a retail firm. Industrial Relations, 49(1), $1-22$.

Kim, K. Y., Pathak, S., \& Werner, S. (2015). When do international human capital enhancing practices benefit the bottom line? An ability, motivation, and opportunity perspective. Journal of International Business Studies, 46(7), 784-805.

Lin, S., Lin, J. S., \& Lin, Y. (2012). Human resource management practices affecting organizational commitment: A study on CEO's transformational leadership. African Journal of Business Management, 6(22), 6575-6586.

Lyons, P. (2009). Action theory and the training and performance application: Performance templates. Industrial and Commercial Training, 41(5), 270-279.

Mahal, P. K. (2012). HR practices as determinants of organizational commitment and employee retention. The IUP Journal of Management Research, 11(4), 37-53.

Marin-garcia, J. A., \& Tomas, J. M. (2016). Deconstructing AMO framework: A systematic review. Intagible Capital, 12(4), 1040-1087.

Meyer, J. P., \& Allen, N. J. (1991). A three-component conceptualization of organizational commitment. Human Resource Management Review, 1(1), 61-89. 
Minbaeva, D. B. (2012). Strategic HRM in building micro-foundations of organizational knowledge-based performance. Human Resource Management Review, 23(4), 378-390.

Moynihan, L. M., Gardner, T. M., \& Wright, P. M. (2002). High performance HR practices and customer satisfaction: Employee process mechanisms (CAHRS Working Paper No. 02-09). Retrieved from https:// digitalcommons.ilr.cornell.edu/cgi/viewcontent.cgi?referer $=$ https:// www.google.com.my/\&httpsredir $=1 \&$ article $=1049 \&$ context $=$ cahrswp

Mulolli, E., Islami, X., \& Skenderi, N. (2015). Human resource management practices and SMEs performance: Study based in Kosovo. International Review of Management and Business Research, 4(4), 1171-1180.

National SME Development Council. (2012). SME Master Plan 2012-2020. National SME Development Council, Kuala Lumpur.

National SME Development Council. (2015). SME Annual Report 2015/2016. National SME Development Council, Kuala Lumpur.

Zakaria, N., Mohamed Zainal S. R., \& Mohd Nasurdin, A. (2011). Investigating The role of human resource management practices on the performance of SME: A conceptual framework. Journal of Global Management, 3(1), 80-98.

Obeidat, S. M., Mitchell, R., \& Bray, M. (2016). The link between high performance work practices and organizational performance: Empirically validating the conceptualization of HPWP according to the AMO model. Employee Relations, 38(4), 578-595.

Osa, I. G., \& Amos, I. O. (2014). The impact of organizational commitment on employees productivity: A case study of Nigeria Brewery, PLC. International Journal of Research in Business Management, 2(9), 107-122.

Rowley, J. (2014). Designing and using research questionnaires. Management Research Review, 37(3), 308-330. 
Schimansky, S. (2014). The effect of a high-commitment work system on innovative behavior of employees. Paper presented at the $3^{\text {rd }} I B A$ Bachelor Thesis Conference. Retrieved from https://essay.utwe nte. nl/65249/1/Schimansky_BA_MB.pdf

Sendogdu, A. A., Kocabacak, A., \& Guven, S. (2013). The relationship between human resource management practices and organizational commitment: A field study. Procedia-Social and Behavioral Sciences, 99, 818-827.

Shin, D., \& Konrad, A. M. (2014). Causality between high-performance work systems and organizational performance. Journal of Management, 43(4), 973-997.

Shore, L. M., \& Tetrick, L. E. (1991). A construct validity study of the survey of perceived organizational support. Journal of Applied Psychology, 76(5), 637-643.

Snell, S. A., \& Dean, J. W. (1992). Integrated manufacturing and human resource management: A human capital perspective. The Academy of Management Journal, 35(3), 467-504.

Subramaniam, C., Faridahwati Mohd Shamsudin, \& Hadziroh Ibrahim. (2011). Linking human resource practices and organisational performance: Evidence from small and medium organisations in Malaysia. Jurnal Pengurusan, 32, 27-37.

Szamosi, L. T. (2006). Just what are tomorrow's SME employees looking for? Education \& Training, 48(8/9), 654-655.

Vandenberg, R. J., Richardson, H. A., \& Eastman, L. J. (1999). The impact of high involvement work processes on organizational effectiveness. Group \& Organization Management, 24(3), 300-339.

Wayne, S., Shore, L. M., \& Liden, R. C. (1997). Perceived organizational support and leader- member exchange: A social exchange perspective. The Academy of Management Journal, 40(1), 82-111. 
Yang, H., Sanders, K., \& Bumatay, C. P. (2012). Linking perceptions of training with organizational commitment: The moderating role of selfconstruals. European Journal of Work and Organizational Psychology, 21(1), 125-149.

Zopiatis, A., Constanti, P., \& Theocharous, A. L. (2014). Job involvement, commitment, satisfaction and turnover: Evidence from hotel employees in Cyprus. Tourism Management, 41, 129-140. 